\title{
A new karren feature: hummocky karren
}

\author{
Lukas Plan ${ }^{1}$, Christa Renetzeder ${ }^{2}$, Rudolf Pavuza ${ }^{3}$, and Wilfred Körner ${ }^{4}$
}

\begin{abstract}
:
Plan L., Renetzeder C., Pavuza R. and Körner W. 2012. A new karren feature: hummocky karren. International Journal of Speleology, 41(1), 75-81. Tampa, FL (USA). ISSN 0392-6672. http://dx.doi.org/10.5083/1827-806X.41.1.8.

Karren are small-scale landforms on karst surfaces and many types have been described so far. Here we present an apparently new feature which was found on the Hochschwab karst massive in the Northern Calcareous Alps of Austria. So far only few outcrops each having less than $1 \mathrm{~m}^{2}$ within a very restricted area have been found. Morphometric analysis reveals that the karren consist of a randomly distributed, dispersed assemblage of small hummocks and depressions in between. The mean distance between neighbouring hummocks is 4 to $5 \mathrm{~cm}$ and the mean height is $0.85 \mathrm{~cm}$. Longitudinal sections are gently sinuous. The occurrences are delimited by thin soil cover with grassy vegetation and the karren continue below that vegetation cover. Therefore, it is clear that the features have formed subcutaneously. Corroded fissures where water could infiltrate into the epikarst are absent. The bedrock lithology is Middle Triassic limestone of the Wetterstein Formation in lagoonal facies. Geological structures do not govern the feature. The surface is not a bedding plane and small joints and fractures do not govern the arrangement of the hummocks. Thin section analysis regarding rock texture and dolomite components show that there is no compositional difference between hummocks and depressions. Geochemical analyses show that the limestone is very pure with a very low content of Magnesia. Slightly higher Magnesia contents at the hummock surfaces are significant. The data obtained so far only indicate that some dissolution mechanism but not any rock property governs the irregular array. As there exist no descriptions of comparable features in literature, the name "hummocky karren" is suggested for that type of karren landform.
\end{abstract}

Keywords: karren; karst landforms; limestone dissolution; Hochschwab; Austrian Alps

Received 29 June 2011; Revised 15 November 2011; Accepted 15 November 2011

\section{INTRODUCTION}

Karren are small-scale dissolution pit, groove and channel forms at the surface or underground. Ford \& Williams (2007) define karren (in contrast to microkarren and karren-fields) as features with a greatest dimension or characteristic dimension from $1 \mathrm{~cm}$ to $10 \mathrm{~m}$ in most instances.

A great variety of karren forms has been described and several attempts exist to classify karren according to the presence or absence of soil cover, genetical processes, size, and topography, to mention just some (e.g. Bögli, 1978; Fornós \& Ginés, 1996; Ginés, 2004).

${ }^{1}$ Natural History Museum, Cave and Karst Department, Museumsplatz 1/10, A-1070 Wien, Austria (*lukas.plan@nhmwien.ac.at)

${ }^{2}$ University of Vienna, Department of Conservation Biology, Vegetation Ecology and Landscape Ecology, Rennweg 14, 1030 Wien, Austria (christa.renetzeder@univie.ac.at)

${ }^{3}$ Natural History Museum, Cave and Karst Department, Museumsplatz 1/10, A-1070 Wien, Austria (rudolf.pavuza@, nhm-wien.ac.at)

${ }^{4}$ University of Vienna, Department for Department of Environmental Geosciences Althanstrasse 14, 2C182, A-1090 Wien, Austria (wilfried.koerner@univie.ac.at)
Two recent monographs entirely devoted to karren landforms present the latest state of knowledge (Ginés et al., 2009; Veress, 2010). However, the exact genetic mechanisms of some forms remain rather speculative.

During karst morphological mapping of the Hochschwab karst massif (Plan \& Decker, 2006) an apparently so-far undescribed karren form was discovered. It consists of small hummocks and depressions in between that are clearly the results of a weathering process and not of a lithologic inhomogeneity.

The objective of this paper is a detailed description of the feature including the surroundings as well as morphometrical, geostatistical, lithological and chemical analysis. The name hummocky karren is suggested.

\section{STUDY AREA \\ Geography and location of test sites}

The Hochschwab, located in the Austrian province of Styria, is one of the major karst massifs in the Northern Calcareous Alps (NCA) covering an area of some $600 \mathrm{~km}^{2}$. It is surrounded by rather deep valleys with floors at 500 to $700 \mathrm{~m}$ while the summit is $2277 \mathrm{~m}$ asl (Fig. 1). 


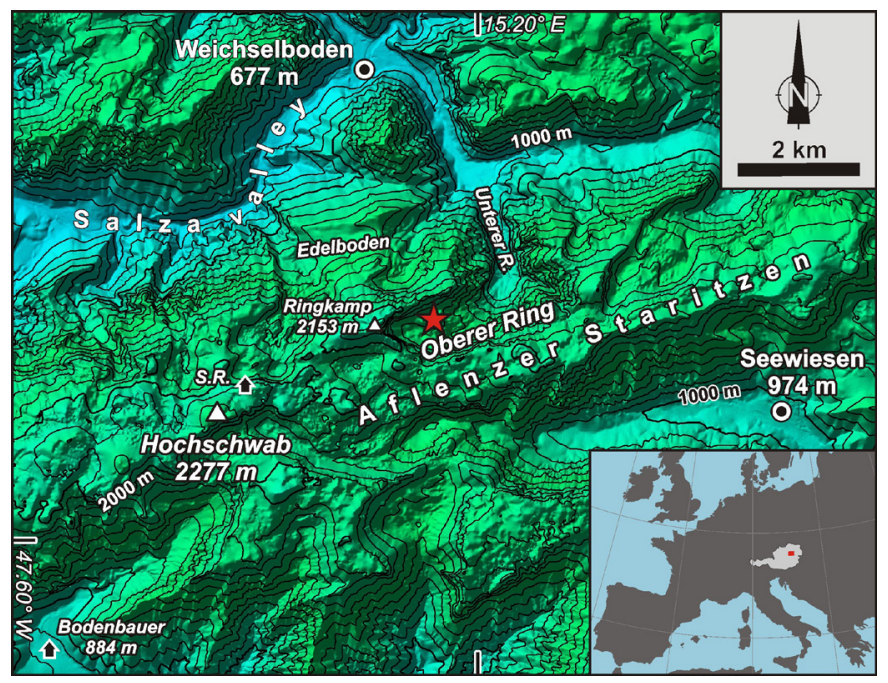

Fig. 1. Location of the study site (red star) on the eastern Hochschwab massif (S.R.: Schiestl Refuge; spacing of isohypses: $100 \mathrm{~m}$ ).

The features were discovered in the Oberer Ring lying south of the village of Weichselboden on the north side of the Hochschwab massif. The Oberer Ring is a glacial cirque that is deeply incised into the eastern plateau of the Hochschwab, called Aflenzer Staritzen. At its bottom the cirque is $0.5 \mathrm{~km}$ wide and extends $3.5 \mathrm{~km}$ from west to east where a drop leads down to a glacial valley called Unterer Ring. The surrounding walls are 400 to $500 \mathrm{~m}$ high and the elevation is $1700 \mathrm{~m}$ in the west below the local summit of Ringkamp $(2153$ $\mathrm{m})$ and $1400 \mathrm{~m}$ above the step that leads down (Fig. 2).

Until now hummocky karren were only found in a very restricted area within the Oberer Ring. The site is characterized by grassy vegetation where single rock outcrops occur as soil was eroded. Three outcrops were investigated in detail (Fig. 3). These outcrops are within $15 \mathrm{~m}$ radius. UTM-coordinates of this area are: 33N; E: 514 350; N: 5275 580. The ground elevation is $1640 \mathrm{~m}$ a.s.1.

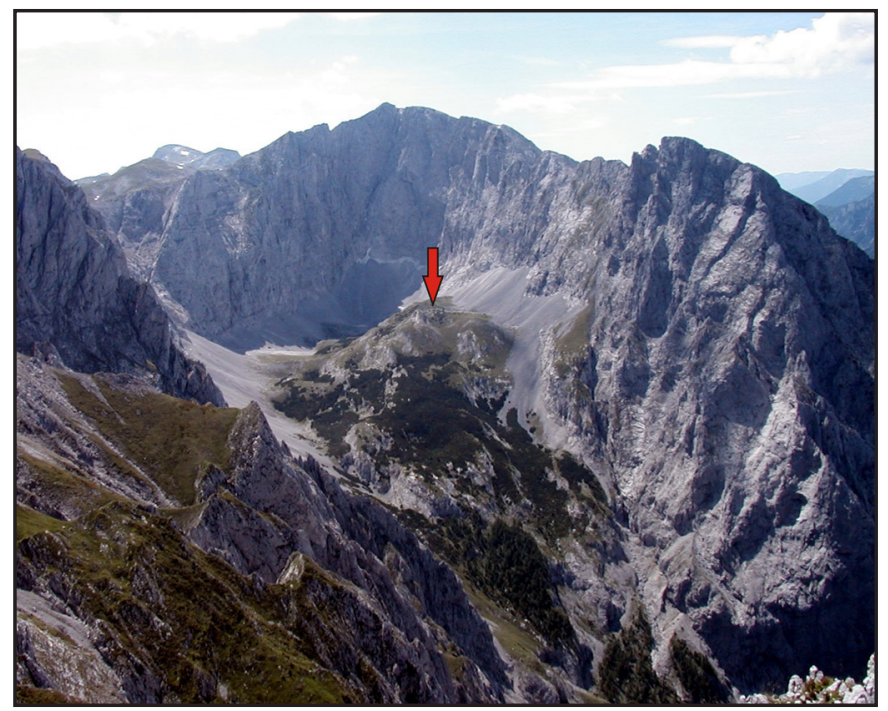

Fig. 2. View from the east into the Oberer Ring, which was eroded into the Hochschwab massif. The headwall below Ringkamp summit (2153 m; middle of picture) is $450 \mathrm{~m}$ high. Arrow indicates site of karren occurrences.

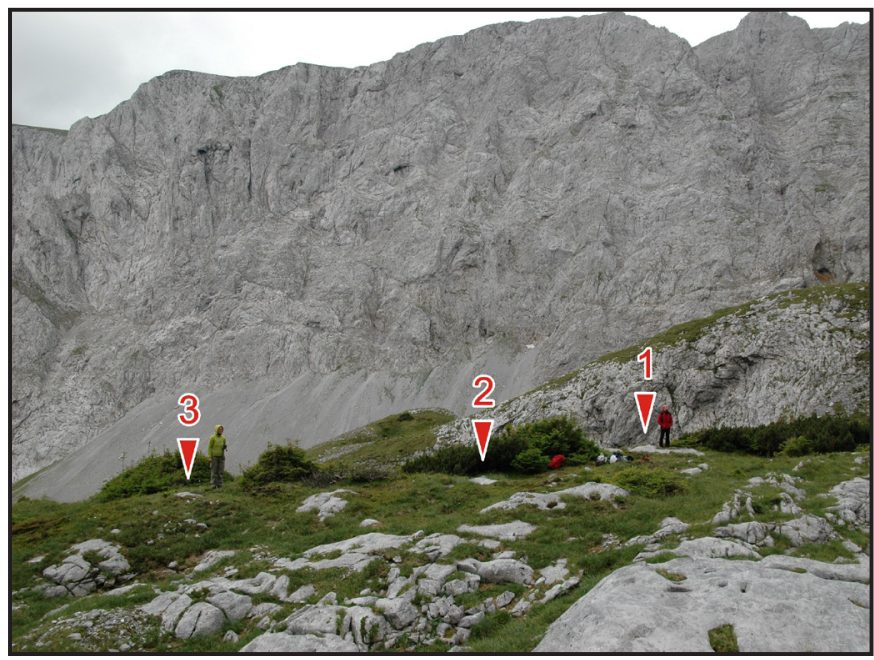

Fig. 3. Location of the three nearby test sites in the Oberer Ring. View towards the south.

\section{Geology}

The Hochschwab is part of the Upper Austroalpine and the study area is located in the Juvavic Mürzalpen Nappe (Mandl et al., 2002). The stratigraphic sequence exposed in the area comprises up to about $2 \mathrm{~km}$ thick Permian to Upper Triassic sediments dominated by Middle Triassic carbonates. The Oberer Ring is built up of Middle Triassic limestone of the Wetterstein Formation in lagoonal facies showing vague bedding in the order of 5 to $10 \mathrm{~m}$.

The Hochschwab massif was part of the alpine ice stream network at least during the Riss glaciation and showed local glaciation separated from the ice stream network in the Würm (Van Husen, 2000). Some Roches Moutonnées in Oberer Ring underline a glacial origin of the cirque (Plan \& Decker, 2006).

\section{Climate and vegetation}

The Hochschwab region is characterized by alpine climate with heavy snowy winters and partly rainy summers. In winter snow piles up to some meters. Climate data for nearby stations is given in Table 1 .

Table 1. Climate data for the period Jan. 2007 until Dec. 2010 (provided by the Vienna Waterworks except for * which is taken from Wakonigg, 1980; MAAT: mean annual air temperature).

\begin{tabular}{|l|c|c|c|}
\hline \multicolumn{1}{|c|}{ Location } & $\begin{array}{c}\text { elevation } \\
{[\mathrm{m} \text { asl.] }}\end{array}$ & $\begin{array}{c}\text { MAAT } \\
{\left[{ }^{\circ} \mathrm{C}\right]}\end{array}$ & $\begin{array}{c}\text { precipitation } \\
{[\mathrm{mm} / \mathrm{a}]}\end{array}$ \\
\hline Weichselboden & 677 & +6.9 & 1186 \\
\hline Edelboden & 1344 & +4.5 & 1610 \\
\hline Schiestl Refuge & 2153 & -0.2 & $\sim 2200^{*}$ \\
\hline
\end{tabular}

In Oberer Ring, due to the north sided position and the narrow shape of cirque the present timberline is shifted down to about $1300 \mathrm{~m}$ asl. (normally being around $1600 \mathrm{~m}$ on the Hochschwab) with single larch trees reaching up to some $1450 \mathrm{~m}$. Dense dwarf mountain pines (Pinus mugo) occur up to about $1600 \mathrm{~m}$ and above there are only single patches. The rest is covered by grassy vegetation, where soil coverage has not been washed out due to karstification or erosion. 
The vegetation at the outcrops is dominated by a mosaic of Festuca pumila-Agrostis alpina (alpine bentgrass) grassland, with occurrences of Caricion firmae species in the neighbourhood of subalpine mountain pine associations (Erico-Pinion mugo). This grassland association might be a replacement association for the mountain pines (Dirnböck et al., 1999).

The soil is characterized by the agglomeration of organic matter whereas at the edges of the outcrops soil erosion is taking place.

\section{Karst features}

The Oberer Ring is drained entirely subsurface and shows a lot of karst features including dolines with up to $50 \mathrm{~m}$ diameter and $10 \mathrm{~m}$ depth and some, mainly unexplored vadose pits. Besides that elongated glaciokarstic depressions with more than $500 \mathrm{~m}$ length occur, formed by glacial erosion and karstification (Plan \& Decker, 2006).

On bare rock surfaces Karren are frequent whereas subcutaneously formed ones are dominant. They comprise kluftkarren, rundkarren, hohlkarren, and up to $1 \mathrm{~m}$ deep mäanderkarren. Originally uncovered forms consist of small rillenkarren and kamenitzas.

Karst denudation rates were investigated on a nearby profile from Weichselboden up to the Ringkamp by measuring the mass difference of 70 carbonate tablets for one year (Plan, 2005). For subcutaneous samples dissolution range between 13 and $40 \mu \mathrm{m} / \mathrm{a}$

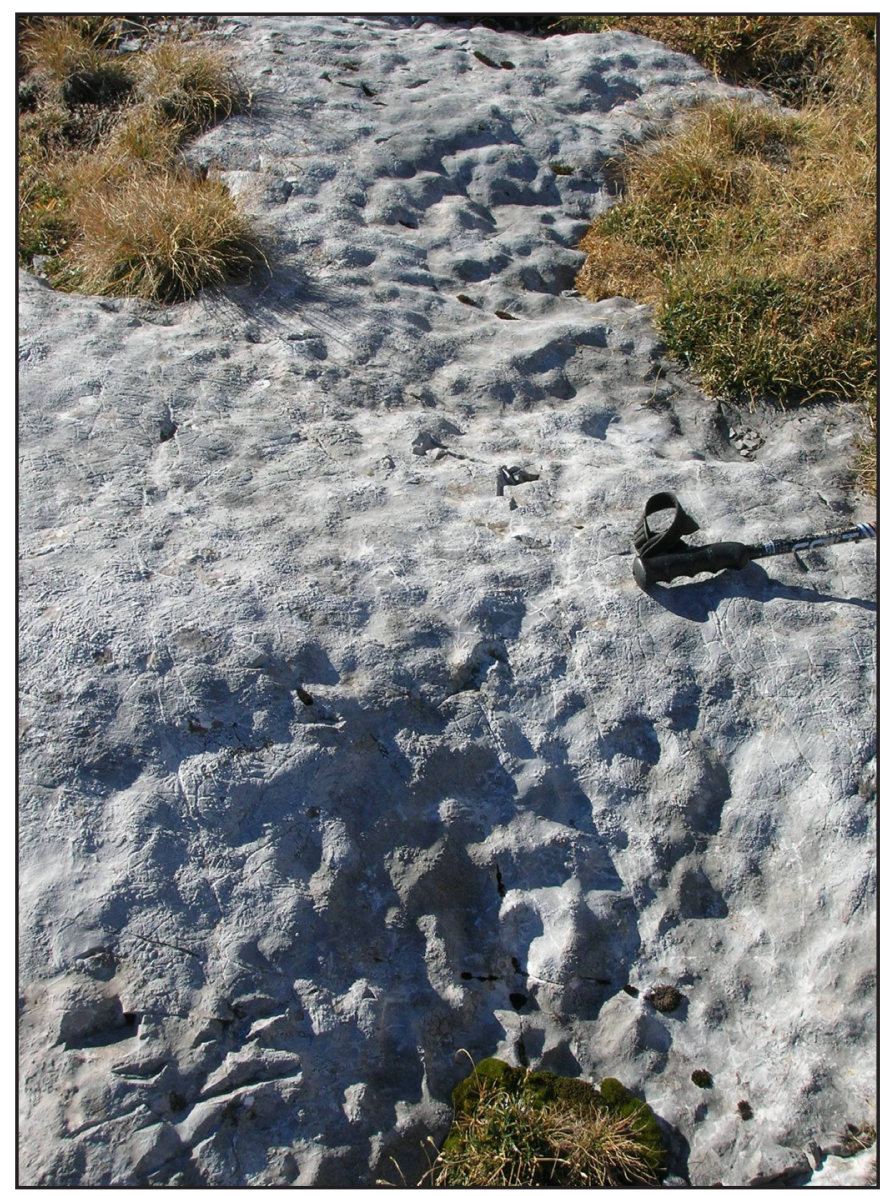

Fig. 4. Hummocky karren (outcrop 1) at flat-angle sun light; Joints impose a microstructure on the surface but do not govern the hummock distribution. Bar end of skiing stick for scale. and for sub-aerially exposure are about $11 \mu \mathrm{m} / \mathrm{a}$. Total dissolution calculated from a mass balance, using high-resolution hydrological data from the Kläffer Spring yielded a rate of $95 \mu \mathrm{m} / \mathrm{a}$ for a catchment area of $83 \mathrm{~km}^{2}$ (Plan, 2005).

\section{METHODS AND RESULTS Morphological description}

All three rock outcrops are on rock surfaces with an average dip of 4 to $12^{\circ}$ to NNE which is similar to the bedding of the limestone (mean 025/10). However, the rock surfaces interpolated between the hummocks are distinctly curved and therefore do not resemble bedding planes. The outcrop sizes vary between 0.4 and $0.9 \mathrm{~m}^{2}$, and they are delimited by soil and vegetation cover.

These outcrops are more or less area wide covered with hummocks and small depressions in between (Fig. 4). If vegetation at the margins is removed it is obvious that the features extend below the soil cover.

The average size of the hummocks is roughly half a decimetre (see below). The peak-to-peak amplitude of the sinuous surface was determined by measuring the longest distances from a reference line held on the hummock tops and the rock surface in between (i.e. the depression). These amplitudes range between 0.3 and $2.0 \mathrm{~cm}$ with a mean amplitude of $0.85 \mathrm{~cm}$ (Fig. 5) without significant differences among the three outcrops.

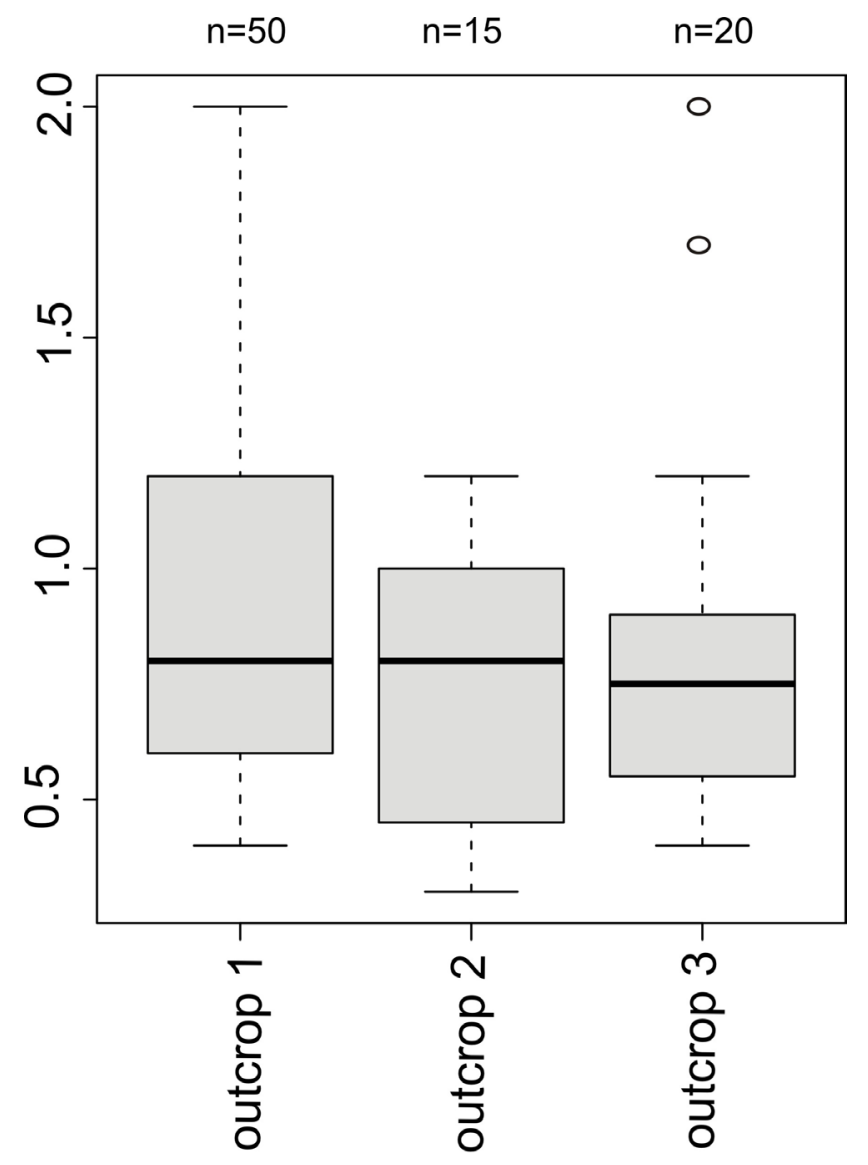

Fig. 5. Whisker plot of the amplitude measures [in $\mathrm{cm}]$ of hummocks for all three outcrops. 

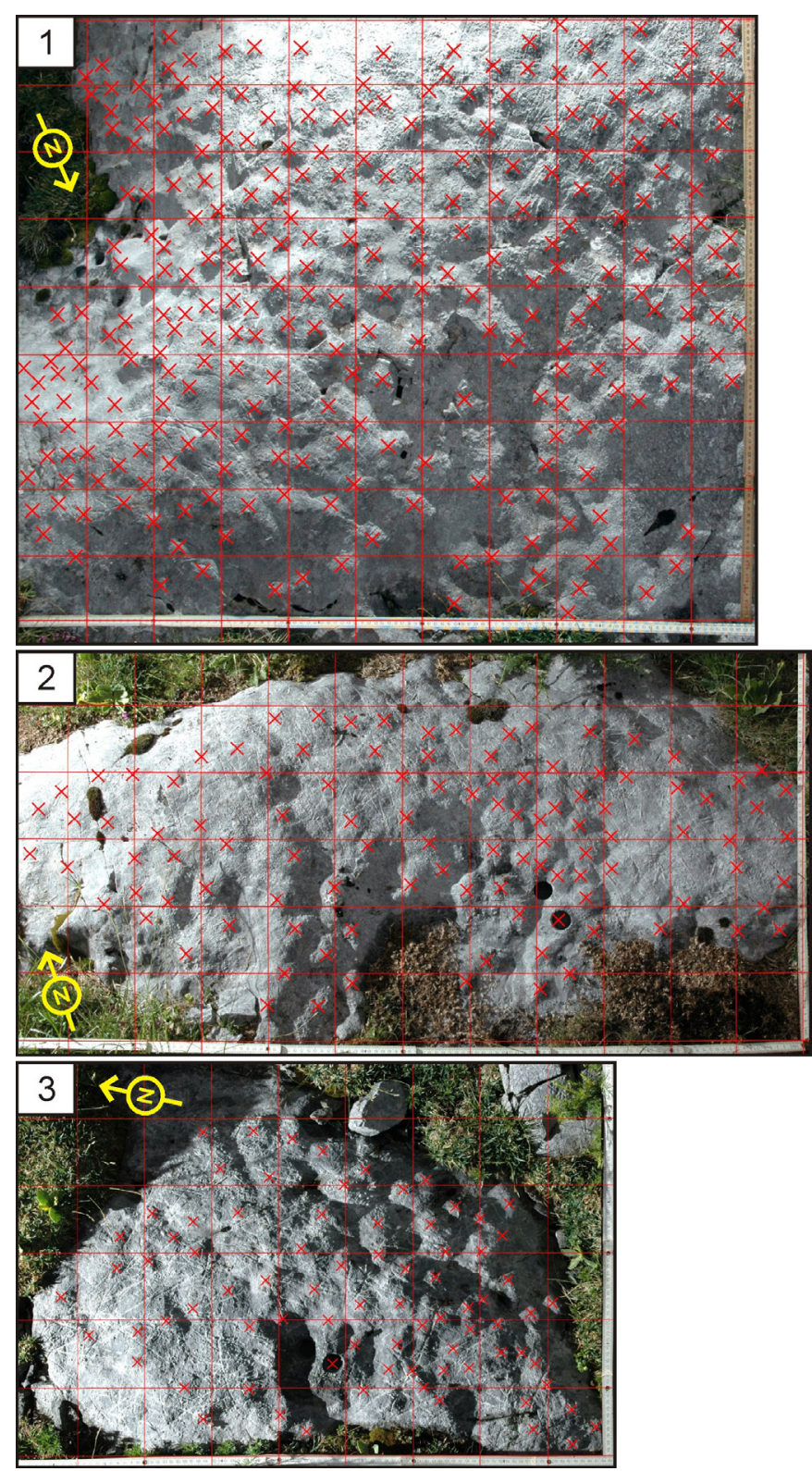

Fig. 6. GIS-Analysis of the three outcrops overlaid with a reference grid of $10 \times 10 \mathrm{~cm}$ in red; red crosses indicate the location of digitized the hummocks. Artificial lighting from the left.
The rock surface shows small joints and fractures, that clearly superimpose a mm-scale microstructure on the rock surfaces and the features but do not govern the arrangement of the hummocks at all. Karstified fissures allowing infiltration into the epikarst are absent within the outcrops.

\section{Morphometric analysis}

In order to statistically analyze the densities and distances of hummocks within each outcrop georeferenced images were analyzed. Therefore the outcrops were photographed perpendicular to the rather planar surface using a flashlight at very low angle above the ground to pronounce the relief. One image of each outcrop was georeferenced in ArcGIS 9.3 with the help of gridlines placed every decimetre.

The highest point of each visible hummock was digitized (Fig. 6). The areal extent of the outcrops ranged from 0.35 to $0.89 \mathrm{~m}^{2}$, and the number of digitized hummocks varied from 80 to 274 .

\section{Point densities}

The intersection of the hummock layer with the $10 \times 10 \mathrm{~cm}$ cells resulted in maps of point densities indicating the distribution of the karren all over the outcrops. In outcrop 1 , the number of hummocks per $d^{2}$ ranged from 1 to 8 (median is 3 ) whereas in outcrop 2 and 3 , the range was 1 to 6 (median $=$ 2) (Fig. 7).

\section{Distances}

Distances among all points were calculated using Hawth's Analysis Tools (Beyer, 2004) giving resulting values of the least distances, the mean distances and the largest distances of each point. Only the minimal distances give meaningful results regarding the differences among the outcrops (Fig. 8). These ranged from $2 \mathrm{~cm}$ to nearly $9 \mathrm{~cm}$, but on average were 4 to $5 \mathrm{~cm}$ in each outcrop.

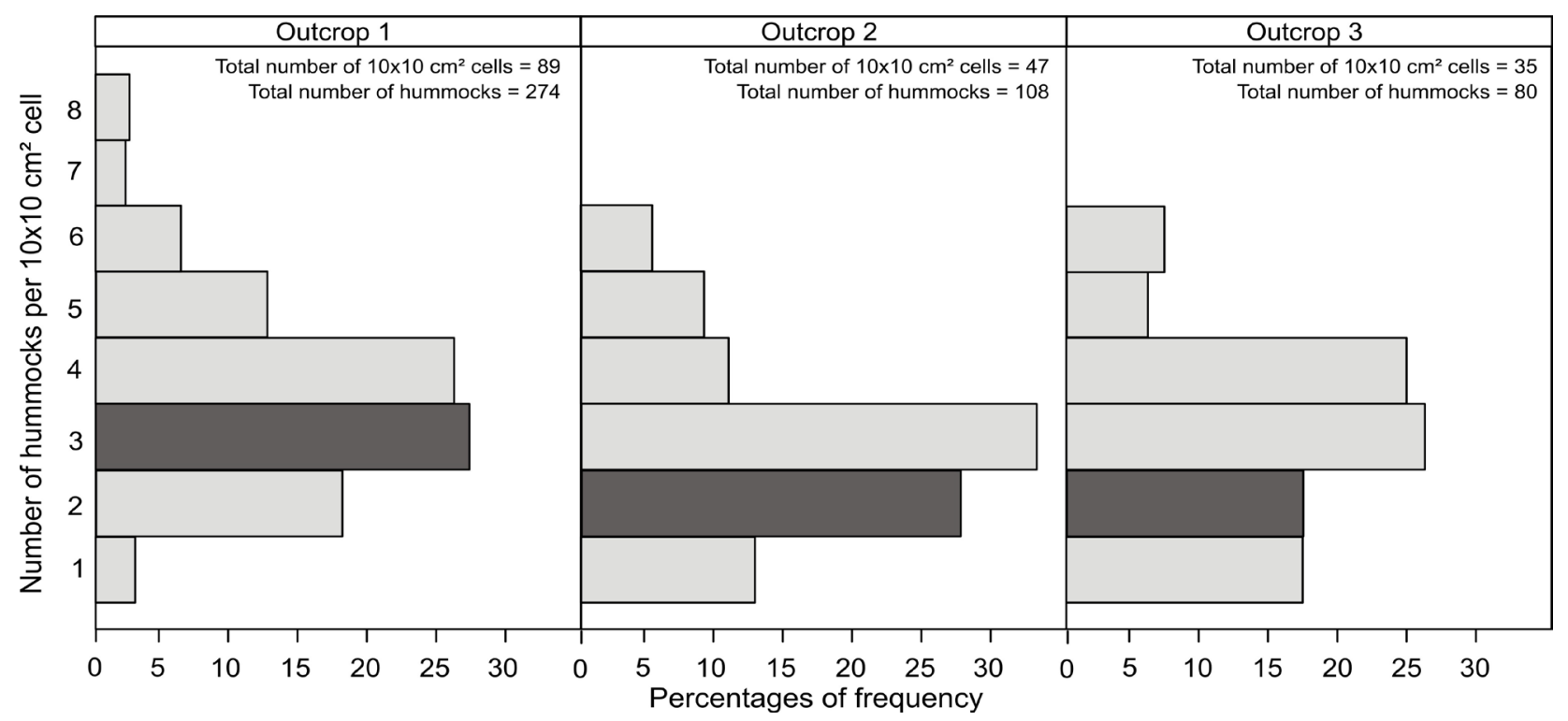

Fig. 7. Frequency of the occurrence of hummocks in each $10 \times 10 \mathrm{~cm}^{2}$ grid cells; median is indicated in dark grey. 


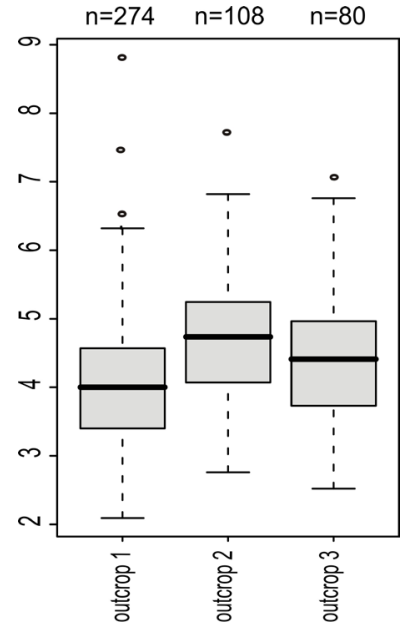

Fig. 8. Minimum distances in $\mathrm{cm}$ between all hummocks showed no significant differences among the outcrops.

\section{Distribution pattern}

Statistical analysis of the distribution pattern was done with the analysis tool "Average nearest neighbor Distance" implemented in ArcGIS 9.3. It measures the distance between each point and its nearest neighbour and then calculates the mean of all these distances (Table 2). This mean is then compared with the average for a hypothetical random distribution and the nearest neighbour index is expressed as the ratio of the observed distance divided by the expected distance. As the nearest neighbour index was bigger than one (index of one indicates a random distribution for all outcrops), we can interpret the distribution pattern of the hummock karren as dispersed (p-value < 0.05).

Table 2. Range of the minimum distances between all hummocks and Index of Average Nearest Neighbour; asterisk indicates significance level of $p$-value $<0.05$.

\begin{tabular}{|l|c|c|c|}
\hline outcrop & 1 & 2 & 3 \\
\hline $\begin{array}{l}\text { Lowest minimum distances } \\
\text { between points [cm] }\end{array}$ & 2.09 & 2.76 & 2.52 \\
\hline $\begin{array}{l}\text { Average minimum distances } \\
\text { between points [cm] }\end{array}$ & 4.06 & 4.70 & 4.43 \\
\hline $\begin{array}{l}\text { Highest minimum distances } \\
\text { between points [cm] }\end{array}$ & 8.82 & 7.72 & 7.05 \\
\hline Nearest neighbor index & $1.39^{*}$ & $1.40^{*}$ & $1.35^{*}$ \\
\hline
\end{tabular}

\section{Geological analysis \\ Sampling}

Four paired core samples of a hummock and an adjacent depression were taken using a gasoline driven drilling machine. One sample set in each outcrop and an additional in the largest one. The drill cores are a few centimetres long and $2.5 \mathrm{~cm}$ in diameter.

\section{Thin section description}

Samples are rich in fossilized material such as dasycladacean, bivalves, corals, foraminifers and gastropods (Fig. 9). The portion of cement varied between about 10 to $40 \%$. The samples can be classified as grapestone (Tucker, 2001) with a slightly varying texture: (1) undisturbed layered texture indicating low circulation and (2) areas of more disturbed environment where material is deposited more unstructured. Therefore we can assume a lagoonal facies with areas of open circulation and of restricted circulation.

However, no differences between the carbonates adjacent to the hummocks and the depression respectively could be detected in the thin sections.

Then the sections were stained using alizarin red in order to highlight dolomite but no distinct dolomite particles were visible under the microscope.

\section{Chemical analysis}

Geochemical data was obtained in two ways: (1) using ICP-AES (inductively coupled plasma atomic emission spectroscopy) and (2) by titration (EDTA) after digestion in carbonic acid to simulate dissolution process which is closer to natural karstification.

To obtain a sample powder from the surface and from certain depth below it a dentist drill was used. For the ICP-AES samples were dissolved in nitric acid $\left(\mathrm{HNO}_{3}\right)$. Analysis was performed on a Perkin Elmer "Optima 5300 DV". Results are given in table 3.

The titration procedure started with the dissolution of the powdered sample in carbonic acid $(\mathrm{pH} \mathrm{4,0)}$ at room temperature to simulate natural dissolution, followed by standard complexometric titration of $\mathrm{Ca}$ and $\mathrm{Ca}+\mathrm{Mg}$ with Titriplex III.

Analysis results of both methods showed that the limestone is quite pure with a low magnesia content having percentages of $\mathrm{Ca} /(\mathrm{Ca}+\mathrm{Mg})$ of over $90 \%$ throughout.

The ratios obtained by the two methods at similar sampling spots do not correlate. While the ICP-AESdata did not show any correlation between samples taken from or below hummocks or depressions respectively (at any depth), the titration data indicated a lower percentage of magnesia at the surfaces of the hummocks than in the depressions (Table 3, Fig. 10).

Whether the difference is due to the different dissolution processes (strong $\mathrm{HNO}_{3}$ versus weak $\mathrm{H}_{2} \mathrm{CO}_{3}$ ) or related to analytical inaccuracies of the low magnesia contents remains ambiguous for the time being.

Table 3. Results of the geochemical analysis using ICP-AES and titration. Gray lines indicate samples at or below hummocks while un-shaded lines indicate depression-samples. Sample-lds are explained in the caption of Fig. 9.

\begin{tabular}{|c|c|c|c|c|c|c|c|c|}
\hline sample & $\begin{array}{c}\text { below } \\
\text { surface } \\
{[\mathrm{cm}]}\end{array}$ & $\begin{array}{c}\mathrm{Ca} \\
{[\% \mathrm{Ox}]}\end{array}$ & $\begin{array}{c}\mathrm{Mg} \\
{[\% \mathrm{Ox}]}\end{array}$ & $\begin{array}{c}\mathrm{Ca} /(\mathrm{Ca}+\mathrm{Mg}) \\
{[\%]}\end{array}$ & $\begin{array}{c}\text { below } \\
\text { surface } \\
{[\mathrm{cm}]}\end{array}$ & $\begin{array}{c}\mathrm{Ca} \\
\mathrm{mg} / \mathrm{l}\end{array}$ & $\begin{array}{c}\mathrm{Ca}+\mathrm{Mg} \\
\mathrm{mg} / \mathrm{ll}\end{array}$ & $\begin{array}{c}\mathrm{Ca} / \\
(\mathrm{Ca}+\mathrm{Mg}) \\
{[\%]}\end{array}$ \\
\hline 1a-d & 0.0 & 40.23 & 1.19 & 97 & & & & \\
\hline 1a-d & 3.0 & 42.95 & 1.63 & 96 & & & & \\
\hline 1a-h & 0.0 & 39.96 & 1.07 & 97 & & & & \\
\hline 1a-h & 4.0 & 42.91 & 1.19 & 97 & & & & \\
\hline 1b-d & 0.0 & 40.56 & 1.73 & 96 & 0.0 & 54.0 & 0.5 & 99 \\
\hline 1b-d & 2.0 & 31.14 & 1.68 & 95 & & & & \\
\hline 1b-h & 0.1 & 40.94 & 1.09 & 97 & 0.0 & 64.0 & 3.7 & 95 \\
\hline 1b-h & 2.0 & 40.09 & 1.15 & 97 & 0.2 & 44.0 & 1.2 & 97 \\
\hline 2-d & 0.0 & 38.40 & 2.86 & 93 & 0.0 & 94.0 & 0.0 & 100 \\
\hline 2-d & 4.0 & 40.55 & 1.38 & 97 & & & & \\
\hline 2-h & 0.0 & 36.98 & 2.61 & 93 & 0.0 & 48.0 & 1.7 & 97 \\
\hline 2-h & & & & & 0.2 & 46.0 & 2.9 & 94 \\
\hline 3-d & & & & & 0.0 & 63.2 & 1.0 & 98 \\
\hline 3-h & 0.0 & 41.64 & 1.62 & 96 & 0.0 & 100.0 & 1.2 & 99 \\
\hline 3-h & 0.5 & 41.59 & 1.15 & 97 & & & & \\
\hline 3-h & 2.0 & 42.08 & 0.91 & 98 & & & & \\
\hline
\end{tabular}




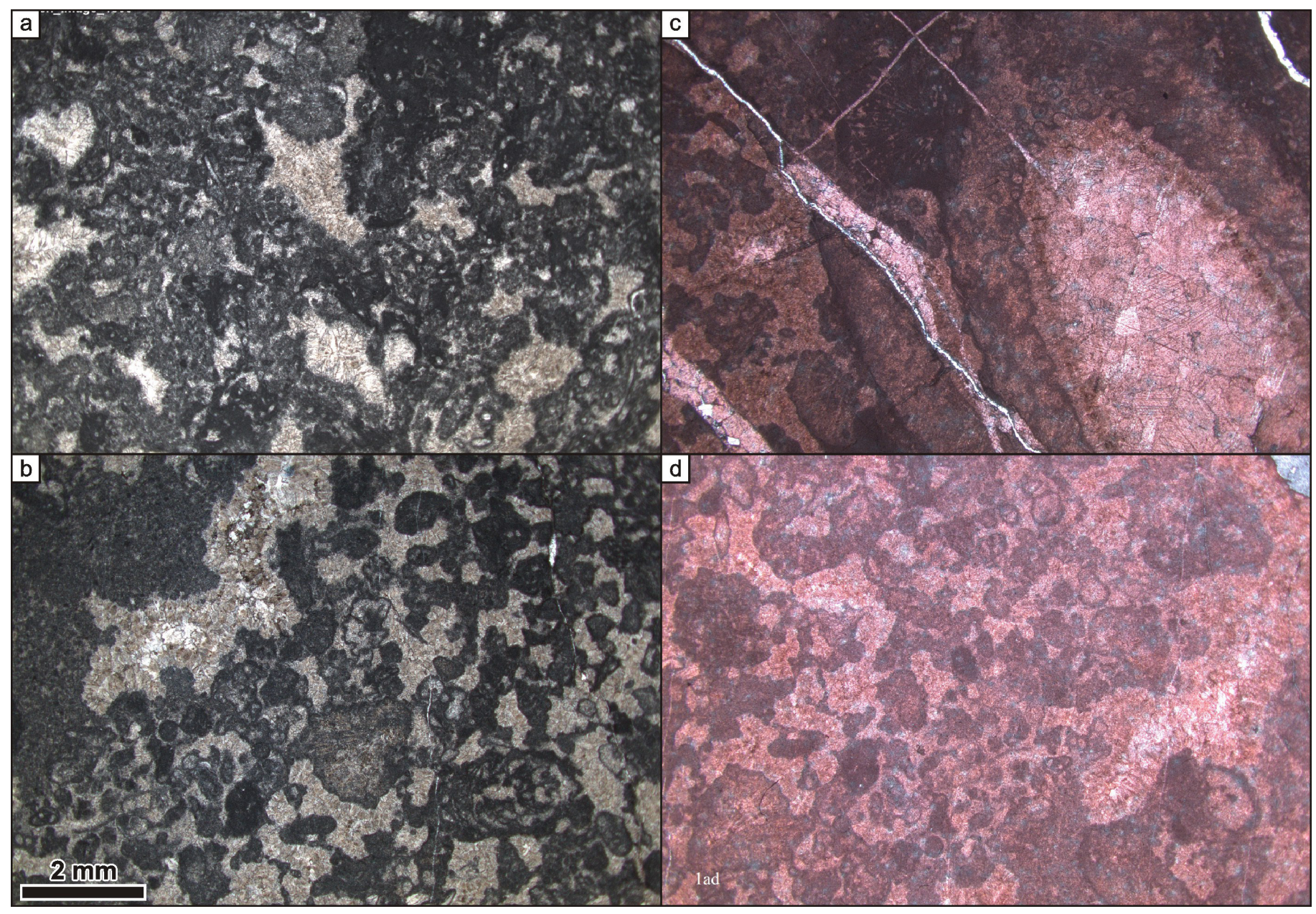

Fig. 9. Examples of limestone thin sections prepared from the drill cores. Sections shown in (c) and (d) were stained using alizarin red, but no dolomite grains are visible. Sample-ld consists of outcrop / drill core number and a suffix for depression (-d) and hummock (-h) respectively: (a): 3-h (i.e. outcrop 3, hummock); (b): 1a-d; (c): 1a-h; (d): 1a-d.

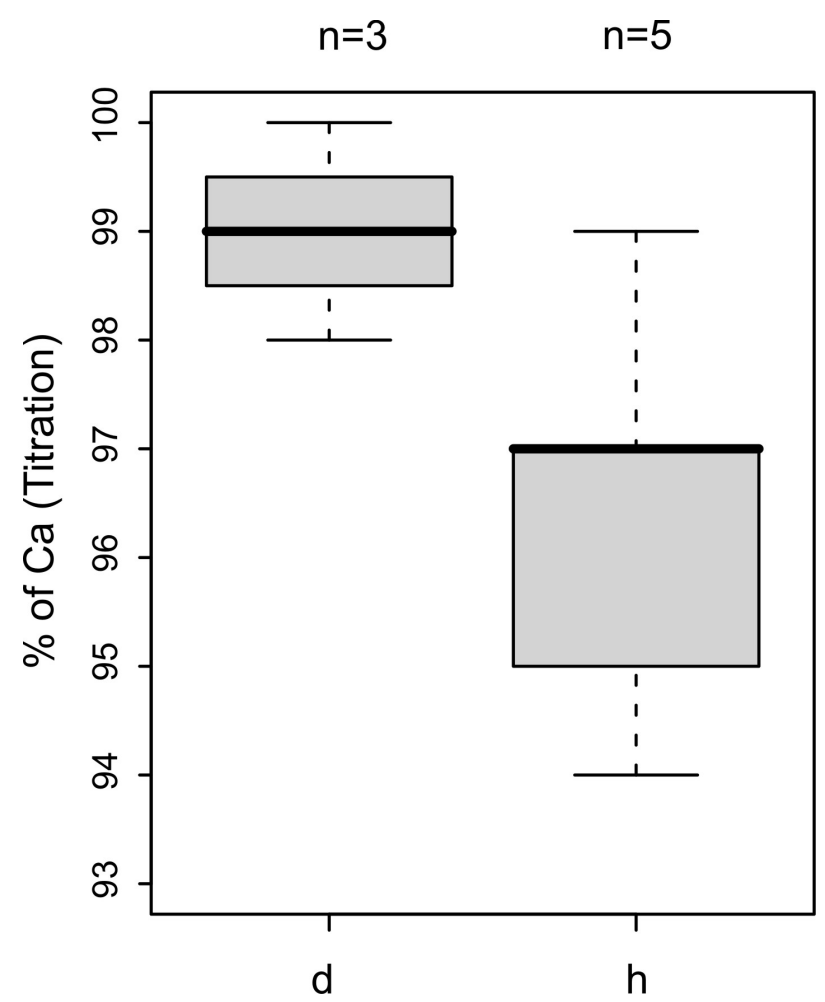

Fig. 10. Whisker plot of titration sample results taken from depressions (d) and hummocks (h).

\section{DISCUSSION AND CONCLUSIONS}

To our knowledge there exist no descriptions of comparable features in literature so far. Therefore, the name "hummocky karren" is suggested for this type of karren landforms. The described feature is not very pronounced and only clearly visible if solar altitude allows shading that emphasizes the gentle relief. This could be a possible reason why the features have not been described before.

For subsoil karren features one should expect that the morphology is highly influenced by both lithology (rock characteristics, mainly texture) and rock structure (joints, fractures, etc.). Karren like surface morphologies similar to the observed ones should be expected on breccias, conglomerates or on nodular limestones, especially on bedding planes.

Surprisingly our observations could not find any evidence for that. Morphometrical analysis revealed a dispersed distribution pattern of the features. But neither geological (thin section analysis) nor geochemical analysis suggest that the surface morphology is the result of a compositional or geochemical inhomogeneity of the host rock. Apart from grains, mainly being fossil particles which are more than one order of magnitude smaller than the hummocks, the limestone is a very homogenous. 
Also tectonic micro structures like joints which are clearly visible do not control the dispersed and polygonal distribution pattern of the hummocks and depressions respectively.

However, the mechanism governing the irregular array and in general the genesis of the hummocks is not yet clear. The only thing obvious is that the described feature is a subcutaneous karren landform that is only related to water seeping along the limestone surface and not to the direct infiltration of water into the epikarst.

Geochemical analysis using titration after digestion in carbonic acid (which is closer to the process of natural karstification) slightly indicates that samples from the rock surfaces of the hummocks have a slightly higher content of magnesia but still clearly represent calcites. However, the number of samples is too low.

More likely, key factors could be some special properties of the soil cover. The genesis of the presented hummocky karren thus can be speculated as follows: The compaction of a thin soil cover due to episodic drying-up causes polygonal soil clusters similar to mud cracks. These inhomogenities in the soil cover influence water and carbon dioxide contents causing local differences in the dissolution-rates of the underlying limestone surface. Nevertheless this model still lacks corresponding field measurements.

According to the classification of karren by Ford \& Williams (2007: 323) the features are circular plan forms and micropits and etched surfaces in detail.

\section{ACKNOWLEDGEMENTS}

We thank Martin Prinz for field assistance. Michael Wagreich and Anton Tanzberger for assistance with carbonate thin section interpretation. Jo De Waele and Derek Ford for scientific discussion. Climatological data were provided by the Vienna Waterworks and processed by Hermann Kain. Joan J. Fornós and Ugo Sauro acted as reviewers and gave helpful comments.

\section{REFERENCES}

Beyer H. L., 2004 - Hawth's Analysis Tools for ArcGIS. http://www.spatialecology.com/htools,

Bögli A., 1978 - Karsthydrographie und physische Speläologie. Springer, Berlin-Heidelberg-New York, 292 p.
Dirnböck T., Dullinger S., Gottfried M. \& Grabherr G., 1999 - Die Vegetation des Hochschwab (Steiermark) - Alpine und Subalpine Stufe. Mitteilungen naturwissenschaftlicher Verein Steiermark, 129: 111-251.

Ford D. \& Williams P., 2007 - Karst Hydrogeology and Geomorphology. John Wiley \& Sons, Chichester, $562 \mathrm{p}$.

Ginés À., 2004 - Karren. - In: Gunn J. (Ed.): Encyclopedia of Caves and Karst Science. Fitzroy Dearborn, New York: 470-473.

Fornós J.J. \& Ginés À., 1996 - Karren Landforms. Universitat de les Illes Balears, Palma de Mallorca, $450 \mathrm{p}$.

Ginés A., Knez M., Slabe T. \& Dreybrodt W., 2009 Karst Rock Features - Karren Sculpturing. Carstologia 9, Založba ZRC / ZRC Publishing, Ljubljana, $561 \mathrm{p}$

Mandl G., Bryda G., Kreuss O., Moser M. \& Pavlik W., 2002 - Erstellung moderner geologischer Karten als Grundlage für karsthydrogeologische Spezialuntersuchungen im Hochschwabgebiet. Unpubl. final report to the Viennese Waterworks, Geologische Bundesanstalt, Wien, 225 p.

Plan L. \& Decker K., 2006 - Quantitative karst morphology of the Hochschwab plateau, Eastern Alps, Austria. Zeitschrift für Geomorphologie, Supplement 147: 29-56.

Plan L., 2005 - Factors controlling carbonate dissolution rates quantified in a field test in the Austrian Alps. Geomorphology, 68: 201-212. http://dx.doi.org/10.1016/j.geomorph.2004.11.014

Tucker M.E., 2001 - Sedimentary Petrology - $3^{\text {rd }}$ Edition. Blackwell Scientific Publications, Oxford, $262 \mathrm{p}$.

Van Husen D., 2000 - Geological processes during the Quaternary. Mitteilungen der Österreichischen Geologischen Gesellschaft, 92: 135-156.

Veress M., 2010 - Karst Environments - Karren Formation in High Mountains. Springer. Heidelberg, London, New York, 230 p.

Wakonigg H., 1980 - Die Niederschlagsverhältnisse im südlichen Hochschwabgebiet. In: Fabiani E., Weißensteiner V. \& Wakonigg H. (Eds.): Grundund Karstwasseruntersuchungen im Hochschwabgebiet, Teil II, Amt der Steiermärkischen Landesregierung, Graz: 65-141. 